\title{
Assessing the Credibility of Best Suited Communication Channels in Rural Communities for Meeting the Unmet Need Towards Reducing Child and Adolescent Marriage: a Model From Upper Egypt
}

Ammal M. Metwally ( $\sim$ ammal_mok@yahoo.com )

National research centre, EG https://orcid.org/0000-0003-0575-5202

Manal H. Abuelela

Research Institute of Ophthalmology

Dalia M. Elmosalami

National Research Centre

Amira Mohsen

National Research Centre

Hala A. Amer

King Saud Medical City

Sherif M. Eldeeb

National Research Centre

Lobna A. El Etreby

National Research Centre

Ghada A. Abdel-Latif

National Research Centre

Marwa M. El-Sonbaty

Taibah University College of Medicine: Taibah University Faculty of Medicine

Hasanin M. Hasanin

National Research Centre

Mohamed A. Abdel Mawla

National Research Centre

Hatem Mohamed Hasan

National Research Centre

Sameh Salama

National Research Centre

Sondos Salem

National Research Centre

Nihad A. Ibrahim

National Research Centre

Hanaa Emam

National Research Centre

Aida M. Abdelmohsen

National Research Centre

Walaa A. Fouad

National Research Centre

Somia I. Salama

National Research Centre

Iman I. Salama

National Research Centre

Rehan M. Saleh

National Research Centre

Research article

Keywords: Child, Adolescent, Marriage, Communication, Channels, credibility

Posted Date: August 10th, 2021 
DOI: https://doi.org/10.21203/rs.3.rs-790266/v1

License: () (i) This work is licensed under a Creative Commons Attribution 4.0 International License. Read Full License 


\section{Abstract}

Background: Low levels of scholarly achievement, poverty, and geographical isolation are all known to be linked to early marriage. This study aimed at identifying the most credible and the best-suited communication channels (CCs) to reach rural communities for motivating them to reduce child and adolescent marriage.

Methods: A cross-sectional study targeted 1000 wives and their husbands were conducted in 21 rural village units of two governorates of Upper Egypt through questionnaires. Decisions concerning the choice of the best-suited communication channels were based on their Reach; Frequency; Managerial feasibility and Effectiveness.

Results: a vast majority of the surveyed wives (96.6\%) were married at an age ranging from 15-24 years. The spread of social media through smartphones was limited to only one-third of wives and their husbands through mainly searching on YouTube (31.7\% of wives and $27.8 \%$ of husbands). Television was the most accessible means of mass media for both wives and husbands ( $72.5 \%$ and $63.3 \%$ respectively). The most credible and the best-suited CCs methods for wives were talking with the health promotors and doctors with two times significantly higher (OR=2.0) than that with the search on YouTube and three times significantly higher $(\mathrm{OR}=3.1)$ than that for social media using browser engine. For husbands, the odds were 1.6 for all.

Conclusions: Despite the availability of recent social media worldwide, rural communities; with high illiteracy, limited access to the internet, and limited availability of smartphones. Interpersonal communication is considered the most effective CCs for achieving equity in reducing child marriage. It seems vital during the implementation of any strategies towards reproductive health to use not only the media broadcasts but also to rely on the channels that are most credible and suitable for the targeted communication to support meeting the unmet need.

\section{Background}

Adolescence is defined as the transition period between childhood and adulthood (between ages 10 and 22 years) although age categories vary among different cultures (1). A recent viewpoint defines the age between 10-24 years as age of adolescence (2).

One third of girls in developing countries are married before the age of 18 and one in nine are married before the age of 15 (3). Though the legal age of marriage has been set at 18 years old since 2008, child marriage is still frequently practiced in Egypt especially in rural communities because the law prohibits but does not criminalize the practice.

Marriage of a young daughter in Egypt allows parents to reduce household expenses and to gain a source of income through the dowry paid to the bride's family. The percentage of women aged 20 to 24 years who were married before the age of 18 had declined from $19.5 \%$ in 2000 to $16.6 \%$ in 2005 , remained steady at $16.6 \%$ from 2005 to 2008 and increased slightly to $17.4 \%$ in 2014 (4). According to the Egypt Census of 2017, child marriage declined with nearly 1 in every 20 girls (5\%) between age 15 to 17 years and 1 in every $10(10 \%)$ adolescent girls $15-19$ years are either currently married or were married before. Meanwhile, large significant differences were observed between rural and urban residence (5) indicating that child marriage remains an important issue among rural communities.

Early marriage deprives girls of education and employment opportunities and places them at risk of early and repeated pregnancy, gender-based violence (GBV) and sexually transmitted infections (STIs) $(6,7)$. Moreover, child and adolescent marriage can refrain economic empowerment in Egypt. Women's opportunity to learn and invade labor market in the future will decrease which can hinder Egyptian economic development, in addition to being a burden as they can experience more complications during pregnancy (8). Moreover, many Egyptian studies concluded that young age at marriage is a cause of education deprivation and acts as a risk factor for child malnutrition and poor development (9-12).

Women living in rural Upper Egypt have less access to high-quality obstetric care, making them about twice as likely to die from pregnancy as women in northern Egypt (13). In 2013, Egypt developed the National Strategic Plan (NSP) for Prevention of Early Marriage, aiming to reduce the prevalence of early marriage by $50 \%$ within a five- year timeframe. However, due to the political situation in Egypt, the plan was not implemented because of the sensitive nature of the problem $(14,15)$. Meanwhile, it is each woman's right to enjoy healthy reproductive life and improving adolescents' care seeking behaviors to have healthy children and happy families (16-18), irrespective to the feasibility of implementing NSP for prevention of early marriage.

The achievement of the global Sustainable Development Goals (SDGs) that are needed for the realization of the national development priorities requires that the beneficiaries and communities are informed about and engaged in the issues that most affect them. Moreover, empowering their decision-makers with knowledge to influence their decisions and improve their lives is necessary. Mass media is one of the popular and cost-effective global public health promotion tools (19) as well local one (18). Mass media (including radio, television, newspapers, magazines, leaflets, posters, and pamphlets) is proved to influence the use of health services.

In response to these findings, it was important to access our target audience and their direct influential decision makers and to dig deeper for identifying the most favorite and credible CCs that are essential for success of strategies needed for effective reproductive health promotion (RHP) for women in general and future adolescents' mothers.

The idea of the present study raised from the belief that any change requires recognizing the voices of those who would be targeted by the development of this change. The realization of equity in health through reducing child and adolescent marriage as a national development priority requires suitable strategies to achieve social movement. For achieving this, our study aimed at assessing the suitable channels of communication that could be used in the future as cost-effective channels helping in changing the behaviors of the target population and achieving development.

Page 3/17 


\section{Methods}

\section{Study Design}

This study was a community based cross sectional systematic formative research. The study was conducted over a period of two years through formative quantitative assessment research for communication channels.

\section{Setting}

Poverty is heavily concentrated in the Upper Rural region of Egypt, where $63.5 \%$ of individuals are poor. This study was conducted in 21 villages of two of the governorates of Upper Egypt which ranked low in socioeconomic standard and high in maternal mortality, namely, Benisuef and Fayoum governorates, which were ranked as the second and the third poorest governorates respectively (20).

\section{Participants}

Two groups were targeted through this study, the first was the direct beneficiaries of reproductive health promotion interventions. Targeted women were ever married women in childbearing period aged 15-49 years within the targeted villages in the selected governorates.

The second was the direct beneficiaries' husbands who were the main decision makers. In the present study, most women mentioned that they followed the beliefs of their husbands for all the life decisions and even for health promotion related issues based on group discussion with the participants. Accordingly, women and their husbands were considered as the priority target groups for the study.

\section{Variables/data sources and measurements}

Quantitative data was obtained through a designed standardized questionnaire that was constructed to determine favorite channels for communication out of the traditional mass media, modern social media and interpersonal communication. The questionnaire included data about the age of wife and husband at first marriage, background information for the education level of the woman and her husband, and their employment status. Decisions concerning the choice of these media were based on reach; what proportion of the target group is exposed to the media? Frequency: how often is the target group exposed to the media? Managerial feasibility: will it be possible for the future interventions to manage the use of the three most exposed media over time? and Effectiveness; what are the most credible information sources, the best-suited communication channels methods, and means to reach the target group? The questionnaire was designed according to UNICEF guidelines 2008, 1999a \& b, and World Bank 2003 (21-25), with some modifications including the addition of social media as modern channel of communication.

The main questionnaire was subjected to pilot testing after its modification on women at their childbearing period attending the rural health units in the same villages that were targeted in Benisuef and Fayoum governorates (50 women from each governorate). Data from these women were not included in the analysis. The pilot test was performed aiming at testing feasibility of the study implementation and assessing the validation of the prepared questionnaire, and its internal consistencies. Based on pilot test, some modifications were done to the questionnaire. Data collection were conducted by a research team from National Research Centre of Egypt.

\section{Sample technique and size}

Sampling: Two-stage random sampling was used; households were randomly selected from the targeted villages in the selected governorates, and then one ever married woman during her childbearing period aged 15-49 years was randomly selected from each household. Selection of the targeted participants was selected after obtaining the map of each village to cover the catchment areas of the targeted 21 villages.

Sampling was conducted to meet the division of reproductive health's standards (DRH) at the center for disease control and prevention of point estimates within $+/-3.5 \%$ (two-sided width $=.07$ ) of the true population prevalence, with $95 \%$ confidence and estimated response rate of $80 \%$. Accordingly, a sample size of 810 produces a two-sided $95 \%$ confidence interval with a width equal to 0.07 , when the sample proportion is $0.5(26,27)$.

The exact sample size was $(810+20 \%$ losses $)=972$ which was rounded up to 1000 . The households were selected randomly. 1000 childbearing women (aged 15-49) and 1000 of their husbands completed the survey.

\section{Quantitative Variables and Statistical Methods}

All completed questionnaire forms were entered in the computer. Statistical Package of Social Science Software program (SPSS), version 18 was used for statistical analyses. Descriptive statistics such as mean, Standard deviation, frequency and percentage were used for data summarization. The analysis was done using, $\mathrm{t}$ test between means, chi-square test and Z-test between proportions. $\mathrm{P}$-value was considered statistically significant when $\mathrm{P}<0.05$ and considered statistically highly significant if $\mathrm{P}<0.01(28)$.

\section{Results}

The study segmented the surveyed women and their husbands regarding their demographic characteristics. Table 1 shows that more than half of the surveyed women (63.7\%) were less than 25 years old which lies in the adolescent age versus one third of their husbands (30.1\%) with a mean age of $23.9 \pm$ 5.8 for wives versus $31.2 \pm 8.4$ for husbands with statistically significant difference $(p<0.001)$. As regards the age at the first marriage, it was noticed that almost two thirds of women $(69.5 \%)$ and one third of husbands $(40.7 \%)$ married at an age less than 19 years with statistically significant difference $(p<$ 
0.001). Moreover, most surveyed women (96.6\%) were married at an age ranging from $15-24$ years versus $83.4 \%$ of husbands, which lies in the adolescent age. 
Table 1

Segmentation of the surveyed women and their husbands according to their demographic characteristics, Upper Egypt

Characteristics

Total Wives $(\mathrm{No}=\mathbf{1 0 0 0})$

Total Husbands $($ No $=1000)$

$\begin{array}{lll}\text { No } & \text { No } & \%\end{array}$

Current age:

$15-<19$

244

24.4

25

2.5

$19-<25$

393

39.3@**

276

27.6

$25-<30$

189

18.9

111

11.1

$30-<35$

98

9.8

412

41.2@*

$35-<40$

58

5.8

131

13.1

40-49

18

1.8

45

4.5

$P$ value of $X^{2}$ (Significance)

$<0.001^{\text {** }}$

Mean current age\#

$23.89 \pm 5.8$

$31.2 \pm 8.4$

(range)

(17-40)

(21-45)

Age at first marriage

$<15$

$15-<19$

37

3.7

36

3.6

$19-<25$

658

65.8@

371

37.1

$\geq 25$

271

27.1

427

42.7@

$P$ value of X2 (Significance)

34

3.4

166

16.6

Mean age at first marriage\#

$<0.001^{\text {** }}$

$19 \pm 3.0$

$25.6 \pm 4.9$

$(16-22)$

$(15-30)$

Education@

1. Illiterate

403

40.3@**

206

20.6

2. Read and write/primary

152

15.2

176

17.6

3. Preparatory

101

10.1

223

22.3

4. Secondary or equivalent (technical-vocational)

307

30.7

372

37.2@*

5. University or more

37

3.7

23

2.3

$P$ value of $X^{2}$ (Significance) $<0.001$ **

Wife employment@

1. Employed

41

4.1

873

87.3

2. Unemployed

959

$95.9 *$

127

$12.7^{* *}$

$P$ value of $X^{2}$ (Significance) $<0.001$ **

Type of husbands' employment:

1.Owner of a business

110

11.0

2.Professional work (employee, engineer, teacher)

171

17.1

3.Labor work (craftsman, builder)

592

$59.2 @ * \star$

4.Others( unemployed, student, pensioner)

127

12.7 


\begin{tabular}{|c|c|c|c|c|}
\hline \multirow[t]{2}{*}{ Characteristics } & \multicolumn{2}{|c|}{ Total Wives $(\mathrm{No}=1000)$} & \multicolumn{2}{|c|}{ Total Husbands $(\mathrm{No}=1000)$} \\
\hline & No & $\%$ & No & $\%$ \\
\hline \multicolumn{5}{|l|}{ Type of residence immediately after marriage } \\
\hline 1. In a house alone with her husband & & & 315 & 31.5 \\
\hline 2. With her parents or one of them & & & 91 & 9.1 \\
\hline 3. With her husband's parents or one of them & & & 481 & 48.1@** \\
\hline 4. With relatives & & & 113 & 11.3 \\
\hline
\end{tabular}

Forty percent of surveyed wives were illiterate versus $20.6 \%$ of their husbands followed by $30.7 \%$ and $37.2 \%$ had secondary or equivalent education for wives and husbands respectively with statistically significant difference between their pattern of distribution $(p<0.001)$. The great majority of studied women (about $96 \%$ ) were housewives while about $60 \%$ of their husbands had paid work as craftsmen or builders. About half of families included in the survey groups lived with the husband's parents or one of them. On the other hand, about one third of wives had their house alone with their husbands.

TV was the most accessible mean of mass media for both husbands and wives (92.7\%) followed by reading then the radio. The least accessibility was to android mobiles (31.7\% of wives and $34.3 \%$ of husbands with insignificant difference between them followed by computers and/or laptops ( $24.0 \%$ ). When comparing the frequency of exposure of wives to their husbands, wives were significantly more exposed to both watching TV (72.5\% versus $63.3 \%$ ) and to reading (31.3\% versus $18.4 \%$ ) with statistically significant difference between them ( $p$ of $z$ test $<0.05)$. Whereas exposure to the android mobiles was the same for both wives and husbands, the exposure to computers and/or laptops was limited to a small percentage ( $18.2 \%$ of husbands and $10.5 \%$ of wives). When comparing the exposure to traditional media versus modern social media, the exposure of wives and husbands to Television were nearly six and five times than that to the android mobiles ( $\mathrm{OR}=5.6$ and 4.7 respectively) with high statistical significance. On the contrary, exposure to reading and android mobiles was nearly equal among wives $(\mathrm{OR}=0.9)$ and insignificantly lower among husbands $(\mathrm{OR}=0.6)$. Reading sources included newspapers and magazines. Meanwhile, for both wives and husbands, the exposure to Radio were equally significantly less than that of the android mobiles (OR $=0.3$ (Table 2). 
Table 2

Reach (accessibility) and Frequency of the exposure to mass media and social media Channels

\begin{tabular}{|c|c|c|}
\hline Channels & $\begin{array}{l}\text { Wives } \\
\mathrm{N}=1000 \\
\text { no (\%) }\end{array}$ & $\begin{array}{l}\text { Husbands } \\
\mathrm{N}=1000 \\
\text { no (\%) }\end{array}$ \\
\hline \multicolumn{3}{|l|}{ 1) Accessibility to Media } \\
\hline \multicolumn{3}{|l|}{ 1.1 Reach to Traditional Mass Media } \\
\hline • Availability of T.V & $920(92.7)$ & \\
\hline • Reading (Newspapers/ Magazines/ Booklets/Posters)@ & $565(56.7)$ & $774(77.4) \star \star$ \\
\hline - Radio & $326(32.6)$ & \\
\hline \multicolumn{3}{|l|}{ 1.2 Reach to Social Media } \\
\hline •Mobiles@ & $890(89.7)$ & 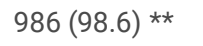 \\
\hline • Availability of Android mobiles@ & $317(31.7)$ & $343(34.3)$ \\
\hline \multicolumn{3}{|l|}{$P$ value of $X^{2}$ (Significance) } \\
\hline - Computer and/ or lap top & $240(24.0)$ & \\
\hline \multicolumn{3}{|l|}{ 2) Frequency of Exposure to Media } \\
\hline \multicolumn{3}{|l|}{ 2.1 Frequency of exposure to Traditional Mass Media } \\
\hline •T.V@ & $725(72.5)$ & $633(63.3) * \star$ \\
\hline • Reading (Newspapers/ Magazines/ Booklets/Posters)@ & $313(31.3)$ & $184(18.4)$ ** \\
\hline •Radio@ & $140(14.0)$ & $126(12.6)$ \\
\hline \multicolumn{3}{|l|}{$P$ value of $X^{2}$ (Significance) } \\
\hline \multicolumn{3}{|l|}{ 2.2 Frequency of exposure to Social Media } \\
\hline •Functioning Mobiles@ & $890(89.7)$ & $986(98.6) * \star$ \\
\hline •Android mobiles@ & $317(31.7)$ & $266(26.6)$ \\
\hline •Computer and/ or lap top@ & $105(10.5)$ & $182(18.2)$ ** \\
\hline \multicolumn{3}{|l|}{$P$ value of $X^{2}$ (Significance) } \\
\hline \multicolumn{3}{|l|}{ Odds of Exposure } \\
\hline • OR (95\% Cl) for exposure to TV vs android mobiles@ & $5.6(4.6-6.8) * \star$ & $4.7(3.9-5.7) * \star$ \\
\hline • OR $(95 \% \mathrm{Cl})$ for exposure to reading vs android mobiles@ & $0.9(0.8-1.1)$ & $0.6(0.5-0.7)$ ** \\
\hline - OR (95\%Cl) for exposure to radio vs android mobiles@ & $0.3(0.2-0.4) * *$ & $0.3(0.3-0.5) * *$ \\
\hline Odds Ratio= OR, @ z test between proportions, * $\mathrm{P}$ Value $<\mathrm{C}$ & $05, \star \star P$ Value $<0$ & \\
\hline
\end{tabular}

Assessing the managerial feasibility found that $81.5 \%$ of wives and $74.2 \%$ of husbands who watched TV spent less than 3 hours /day with significant difference between wives and their husbands. Meanwhile, half of the wives and their husbands ( $48.5 \%$ versus $47.0 \%$ respectively) spent $>5$ hours/day on android mobiles for the use of the social media with insignificant difference. For reading there is insignificant preferences for both wives and their husbands (Table 3). Among both husbands and wives who watched TV, satellite channels were much more preferred than local channels with significant statistical difference between them $(p<0.05)$ (Fig. 1). The most favorite programs through which messages could be received by wives and husbands were drama and series (48.4\% and $85.6 \%$ respectively) followed by cooking programs for wives (32.6\%) and specialized programs (talk show) (65.1\%) for husbands with highly significant difference between the wives and their husbands concerning the preference of the favorite programs (<0.001) (Fig. 2). 
Table 3

Managerial feasibility of the three most exposed mass and social media among target audience, Upper Egypt (time of watching TV or using social media)

\begin{tabular}{|c|c|c|c|}
\hline \multirow[t]{2}{*}{ 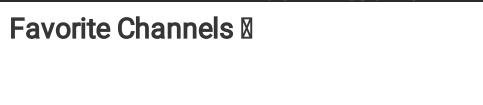 } & Wives & Husbands & $P$ value of $z$ test \\
\hline & No (\%) & \multicolumn{2}{|l|}{ No (\%) } \\
\hline Watching TV & No $=725$ & \multicolumn{2}{|l|}{ No $=633$} \\
\hline Less than 3 hours/day & $591(81.5)$ & $470(74.2) \star$ & $<0.05^{\star}$ \\
\hline $3-5$ hours/day & $86(11.9)$ & $94(14.8)$ & $<0.05^{\star}$ \\
\hline$>5$ hours/day & $48(6.6)$ & $69(11.0)$ & $<0.001^{\star \star}$ \\
\hline \multicolumn{4}{|l|}{$P$ value of $X^{2}$ (Significance) } \\
\hline Exposure to Social Media on Mobiles & No $=317$ & \multicolumn{2}{|l|}{ No $=266$} \\
\hline Less than 3 hours/day & $130(41.1)$ & $87(32.7)$ & $<0.001$ ** \\
\hline $3-5$ hours/day & $33(10.4)$ & $54(20.3)$ & $<0.001 * \star$ \\
\hline$>5$ hours/day & $154(48.5)$ & $125(47.0)$ & $>0.05$ \\
\hline \multicolumn{4}{|l|}{$P$ value of $X^{2}$ (Significance) } \\
\hline Reading & No $=313$ & \multicolumn{2}{|l|}{ No $=184$} \\
\hline Once a month & $82(26.2)$ & $41(22.3)$ & $<0.001$ ** \\
\hline Once a week & $96(30.7)$ & $49(26.6)$ & $<0.05^{\star}$ \\
\hline 2-3 times a week & $32(10.2)$ & $18(9.8)$ & $>0.05$ \\
\hline Almost every day & $58(18.5)$ & $38(20.7)$ & $>0.05$ \\
\hline Once per day or more & $11(3.5)$ & $14(7.6)$ & $<0.001 * \star$ \\
\hline Irregular & $34(10.9)$ & $24(13.0)$ & $>0.05$ \\
\hline \multicolumn{4}{|l|}{$P$ value of $X^{2}$ (Significance) } \\
\hline \multicolumn{4}{|c|}{ \ calculated out of the most exposed channel, * $\mathrm{P}$ Value $<0.05 * \star \mathrm{P}$ Value $<0.001$} \\
\hline
\end{tabular}

Assessment of the effectiveness for the most credible information sources and the best-suited CCs methods and means to reach the target groups was shown in Table 4. The assessment revealed that the most credible sources of information for receiving messages by most husbands and wives were interpersonal communication with health promoters (39.3\% for husbands and $49.1 \%$ for wives, $(p<0.05)$ followed by doctors $(48.7 \%$ of wives), and nurses (35.5\% of husbands) with significant difference between wives and their husbands $(p<0.05)$. A high percentage of the target group expressed their desire to receive messages through direct talk with doctors ( $58 \%$ of husbands and $65.3 \%$ of wives) or with health promoter ( $44.2 \%$ of husbands and $57 \%$ of wives), with significant difference $(p<0.001)$. TV (as a traditional channel) followed by YouTube videos was the second source ( $38.3 \% \& 27.8 \%$ for husbands and $42.6 \% \& 31.7 \%$ for wives respectively $(p>0.05)$. The third most desirable channel was messaging with friends/relatives/ neighbors through "Whats app" application (27.3\% of husbands and $30.7 \%$ of wives) with insignificant difference. Furthermore, for wives, talk with doctors or health promotors was two times significantly higher as the most credible and favorite channels than that with search on you tube $(\mathrm{OR}=2.0$ \& OR $=2$ respectively) and three times higher than that for social media using browser engine ( $O R=3.1$ for each). For husbands, the odds were nearly one and half for all (Table 4$)$. The second most credible and favorite channels for both wives and husbands were TV which carry more than one and half times significantly higher incidence than that with search on you tube ( $\mathrm{OR}=1.5 \& 1.6$ respectively) or social media ( $\mathrm{OR}=2.4 \& \mathrm{OR}=1.5$ respectively). 
Table 4

Listing of channels through which messages for reproductive health promotion were received by target audience (most credible information source versus the most favorite), Upper Egypt

\begin{tabular}{|c|c|c|c|c|}
\hline \multirow[t]{4}{*}{ Channels } & \multicolumn{2}{|l|}{ Wives } & \multicolumn{2}{|l|}{ Husbands } \\
\hline & \multicolumn{2}{|l|}{$N=1000$} & \multicolumn{2}{|l|}{$N=1000$} \\
\hline & \multicolumn{2}{|l|}{$\mathrm{No}(\%)$} & \multicolumn{2}{|l|}{ No(\%) } \\
\hline & Most credible & Most favorite & Most credible & Most favorite \\
\hline \multicolumn{5}{|l|}{ Social Media } \\
\hline • Search on YouTube@ & $317(31.7)$ & $317(31.7)$ & $278(27.8)$ & $268(26.8)$ \\
\hline • messaging with friends/relatives/ neighbors through whatsApp@ & $132(13.2)$ & $307(30.7)$ ** & $113(11.3)$ & $273(27.3) * \star$ \\
\hline - Social media through Facebook group and /or twitter@ & $233(23.3)$ & $192(19.2) *$ & $285(28.5)$ & $314(31.4)$ \\
\hline - Search through search browser engine (e.g Google, Microsoft edge...etc) @ & $10(1.0)$ & $70(7.0) * *$ & $35(3.5)$ & $85(8.5) * *$ \\
\hline \multicolumn{5}{|l|}{ Traditional Mass Media } \\
\hline •T.V@ & $426(42.6)$ & $74(7.4) \star \star$ & $383(38.3)$ & $163(16.3) * \star$ \\
\hline • Newspapers/ Magazines/ Booklets/Posters@ & 104(10.4) & $537(53.7)$ ** & $99(9.9)$ & $545(54.5) * \star$ \\
\hline •Radio@ & $91(9.1)$ & $90(9.0)$ & $66(6.6)$ & $101(10.1)$ * \\
\hline OR $(95 \% \mathrm{Cl})$ for TV vs search on You Tube & $1.5(1.3-1.9) * *$ & & $1.6(1.3-1.9) * *$ & \\
\hline OR $(95 \% \mathrm{Cl})$ for TV vs search on social media & $2.4(2.0-2.9) * \star$ & & $1.5(1.2-1.8) * *$ & \\
\hline \multicolumn{5}{|l|}{ Interpersonal communication } \\
\hline •Religious leaders@ & $150(15.0)$ & $246(24.6) * \star$ & 181(18.1) & $316(31.6) * \star$ \\
\hline • Talk with partner@ & $257(25.7)$ & $279(27.9)$ & $241(24.1)$ & $292(29.2) *$ \\
\hline •Talk with Doctors@ & 487(48.7) & 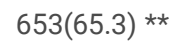 & $348(34.8)$ & $580(58.0) * \star$ \\
\hline OR $(95 \% \mathrm{Cl})$ for Talk with the doctor vs search on You Tube & $2.0(1.7-2.4) * \star$ & & $1.3(1.1-1.6)$ ** & \\
\hline OR $(95 \% \mathrm{Cl})$ for Talk with the doctor vs search using browser engine & $3.1(2.5-3.7)$ ** & & $1.3(1.1-1.6) * *$ & \\
\hline •Talk with Nurses@ & $417(41.7)$ & $498(49.8)$ * & $355(35.5)$ & $446(44.6) * \star$ \\
\hline OR $(95 \% \mathrm{Cl})$ for Talk with the nurse vs search on You Tube & $1.5(1.2-1.8)$ ** & & $1.4(1.1-1.7)$ ** & \\
\hline OR $(95 \% \mathrm{Cl})$ for Talk with the nurse vs search using browser engine & $2.3(1.9-2.8)$ ** & & $1.3(1.1-1.6)$ ** & \\
\hline • Talk with Health Promoters (HPs) @ & $491(49.1)$ & $570(57.0)$ * & 393(39.3) & $442(44.2)$ * \\
\hline OR $(95 \% \mathrm{Cl})$ for Talk with the health promoter vs search on You Tube & $2.0(1.7-2.4) * *$ & & $1.6(1.3-2.0) * \star$ & \\
\hline OR $(95 \% \mathrm{Cl})$ for Talk with the health promoter vs search using browser engine & $3.1(2.6-3.8) * *$ & & $1.6(1.3-1.9) * *$ & \\
\hline
\end{tabular}

Reproductive health promotion messages that were most received by the target group were those about risky pregnancy (58.6\% of wives and $48.7 \%$ of husbands) and family planning (31.6\% of husbands and $51.6 \%$ of wives). Statistically significant difference was observed for all the messages received in favor of wives except the messages related to reproductive tract infection (Table 5). 
Table 5

Messages for reproductive health promotion received by husbands and wives, Upper Egypt as reported by participants

\begin{tabular}{|llll|}
\hline Channels & Wives & Husbands & $P$ value of $z$ test \\
& $N=1000$ & $\mathrm{~N}=1000$ & \\
& $\mathrm{No}(\%)$ & $\mathrm{No}(\%)$ & \\
\hline Pregnancy and labor and their risks including risk of abortion & $586(58.6)$ & $487(48.7)$ & $<0.001^{\star *}$ \\
\hline Messages about family planning and spacing & $516(51.6)$ & $316(31.6)$ & $<0.001^{* *}$ \\
\hline Messages about antenatal care, and safe delivery & $456(45.6)$ & $75(7.5)$ & $<0.001^{* *}$ \\
\hline Reproductive tract infection health education messages & $286(28.6)$ & $275(27.5)$ & $>0.05$ \\
\hline Guidelines to safe delivery & $32(3.2)$ & $52(5.2)$ & $<0.05^{\star}$ \\
\hline * P Value $<0.05 * * P$ Value $<0.001$ & & & \\
\hline
\end{tabular}

\section{Discussion}

Important decisions in our lives are not necessarily made by the right, the best or the smartest person but rather by the person who has the power to make that decision especially in young age groups where individuals cannot give consent as in adolescence. Decision makers in any society are a key group that must be targeted and approached due to their direct influence on changing the beliefs and awareness of people living in that society. Many wives in the current study reported that they follow the beliefs of their husbands for all life decisions and even for health promotion related issues. Meanwhile, in rural communities, refusal of husbands was reported by many wives to be the most common barrier to their referral to health services $(17,18,29)$. Moreover, the target audience whose behaviors need to be changed the most may not be the direct beneficiaries from the messages. Often, it is -the "influencers"- the people who influence direct beneficiaries' behaviors- that most need to be informed and to change their concerns and practices.

Targeting the influencers will guarantee effective communication that is needed to affect the environment in which healthy behaviors are requested for adoption, promotion, and sustainability. Based on all the above findings and facts, women and their husbands were considered as the priority target groups for the current study.

The Survey of Young People in Egypt (SYPE) 2014, revealed that 21.1\% of married female youth aged 25-29 years were married before the age of 18 , and $33.3 \%$ of young women residing in rural Upper Egypt were also reported to be married before 18 (6). Accordingly, one of main causes were that female participants in our study let their husbands take the decisions was that many of them were in the adolescent period (63.7\%) or being first married in that period $(96.6 \%)$, which is a critical and transitional period where adolescents cannot yet make their own decisions.

In the field of health, substantial evidence shows that people are willing to change their health behavior irrespective to the health condition. It is therefore important to identify channels of communications through which health promotion (HP) messages that contribute in promotion of reproductive health should be disseminated to the specific target audience. Nowadays, health care messages including reproductive health, are increasingly being delivered through digital channels such as the internet, mobile phone messaging, social media, apps, voice/ video messaging, and telemedicine. These ways have proven to be effective in developed countries, yet in developing countries many barriers such as infrastructure, lack of equipment, and technology gap hinder their successful implementation (29-32).

In the current study, the internet was not a first choice for the participants as a source of reproductive health information as only one third of them had access to android phones. Interpersonal communication appeared to be the most credible source of information and the most favorite channel through which reproductive health promotion messages could be received by target audience. Talking with health promoter (39.3\% for husbands and $49.1 \%$ for wives) and talking with doctors (48.7\% of wives) came as the most important means for both wives and husbands followed by TV (42.6\% of wives and $38.3 \%$ of husbands). This result is like that of many previous old and recent studies as well, who assessed the effectiveness of broadcasted media versus interpersonal channels in delivering health messages to the public (33-38). They reported that in low and moderate socioeconomic societies, interpersonal communication serves as primary health information sources for health- oriented individuals with strong health beliefs and commitment to healthy activities, while passive consumption channels such like television and radio serve as primary health information sources for individuals in low socioeconomic societies and who are not health-oriented. Unfortunately, neither one of these studies assessed the reach, frequency, managerial feasibility nor the effectiveness of the recent social media channels versus the traditional ones as tool for health promotion.

In the present study, on investigating the channels of communication through which reproductive health promotion messages could be disseminated, the percentages of wives who had accessibility to TV, radio and reading media were $72.5 \%, 14 \%$ and $31.3 \%$ respectively, while for the husbands the percentages were $63.3 \%, 12.6 \%$, and $18.4 \%$ respectively. This indicates more accessibility of wives and their husbands to TV as a main source for health information within Egyptian families. TV serials have been proven as a very successful means of 'edutainment" as well.' They usually convey a particular theme which can possibly influence viewers' behavior (39-41).

Assessing the managerial feasibility will help in the identity of the possibilities to be targeted for any future interventions depending on the exposure over time through detecting the top three types of media and platforms to which the target audience were most exposed. The current study found Television stations as key partners in disseminating messages for promoting public health. The current study revealed that the more than three quarters of wives 
(81.5\%) and husbands (74.2\%) spent less than 3 hours per day watching televisions watching drama and series (48.4\% and $85.6 \%$ respectively). This finding was in accordance with an old study dated 1999 that was done by the National Research Council (US) and Institute of Medicine (US) Board on children, youth, and families (42), indicating that the situation still the same in rural communities despite of the nowadays widespread of the social media. Whereas only half of those reported to have android mobiles spent up to five hours per day on android mobiles. This finding indicate that future programs should rely on mass media rather than social media for the large and broad campaigns to target rural communities. An example in Egypt that is proved to be successful one with the use of mass media is a soap opera called "The Family House" which reached out to millions of Egyptians with health messages on issues such as AIDS, drugs, child spacing, home accidents, and hygiene $(43,44)$. Another example is a soap opera on the South African television that was run by public health activists over $70 \%$ of the population addressing, from HIV and AIDS to rape (45).

For wives, talk with doctors or health promotors was two times significantly higher as the most credible information sources and the best-suited CCs methods than that with search on you tube $(O R=2.0 \& O R=2$ respectively) and three times higher than that for social media using browser engine (OR $=3.1$ for each). For husbands the odds were nearly one and half for all. This was in accordance with many Egyptian studies which have achieved their goals for improving behaviors for many health-related diseases and issues with the aid of the health promotors, community leaders or health care workers; e.g reduction of maternal mortality $(17,18,46,47)$, improving environmental health $(48,49)$, alleviating children anemia $(50)$, counteracting barriers against diabetes (51), and accelerating HCV elimination (52-54). These studies are mainly community-based studies in rural communities respecting the culture and believes within their communities. Other Egyptian studies that relay on the nurses and physician for facility-based studies addressing a number of health issues from improvement of cognitive function (55), children nutritional habits (56-58), improving response of HBV among children (59-60) and improving compliance with hemodialysis patients (61-62). All these health communication programs were proved to be helping aid for people make these changes especially for rural communities of Egypt by using the most credible and favorite channels.

\section{Conclusion}

Application of cost-effective strategies for tackling rural health problems required CCs assessment to identify the on-ground situation to meet the unmet need for not only the problem of child and adolescent marriage but for facing any health problem. Despite the availability of recent social media worldwide, what worked worldwide was not the situation for rural communities, with high illiteracy, limited access to the internet, and limited availability of smartphones. For rural communities and with the widespread of many health problems, the most credible information sources and the best-suited CCs methods for delivering reproductive health messages are interpersonal communication through health promoters followed by doctors and nurses. Television, being the most favored and most accessible mass media channel, play important roles in terms of conveying information, stimulating thought, informing, and developing ideal behavior.

\section{Recommendations}

It seems vital during the implementation of any preset strategies for reproductive health to use not only the media broadcasts to promote reproductive health but also to rely on the channels that are most credible and suitable for the targeted communication. For rural communities in special, the used media must be embedded in the settings in which people live through the health promoters in the community setting and by professionals in clinics rather than being delivered through social media. These types of efforts would improve women's and men's abilities to meet their childbearing goals and empower country directions towards fulfillment of the global sustainable development goals to ensure equality by 2030 .

\section{Strengths of the study:}

The current study serves as an exemplary model for facilitating the implementation of the national strategies for RHP mainly in rural communities and support meeting the unmet need. The study did not only assess the availability and accessibility of different CCs but assess their managerial feasibility and credibility as a crucial step for limiting child and adolescents' marriage.

With the still high adolescents' marriage in rural communities of Egypt, this study reports on the problem situation from the holistic point of view and did not dig deeper into linking wives and husbands' characteristics to the use of channels type as it is well known that the use of social media is highly linked with education level and young age.

\section{Limitation of the study}

The study was limited to study only the beneficiaries, without evaluating the impact of CCs use on the reduction of child and adolescent marriage.

\section{Declarations}

\section{Consent to publish}

Not Applicable.

\section{Availability of data and materials}

The datasets used and/or analyzed concerning the current study are not publicly available due to the privacy of the studied women and their husbands as any topic related to reproductive health in rural communities is considered taboo. Meanwhile, all data of the current study are available from the corresponding author on reasonable request. 


\section{Competing interest}

The authors declare no conflict of interest.

\section{Funding}

This study was supported financially by the Science and Technology Development Fund (STDF), Egypt, Grant No 358.

\section{Ethics approval and consent to participate}

The study complied with the International Ethical Guidelines for Biomedical Research Involving Human Subjects (63). Medical Research Ethical Committee National Research Centre of Egypt has cleared the study protocol with ethical approval registration number 10140. Informed written consent was obtained from all participants involved in the study. Information obtained at the individual level was kept strictly confidential. A worthy note to mention that although the study was looking for the child marriage with the age of both wives and their husbands less than 18 years, yet the actual current age of the surveyed women and their husbands were in the age range (17-40 years) and (21-45 years) respectively. All participants were above the age of 16 at the time of their enrollment for the study. Accordingly, there were no need for their parents/guardians consent on their behalf.

\section{Authors' contributions}

AMM conceived and designed the study. RMS, MHA, DME, AM, AHE, HAA, SME, GAA, MME, HMH, MAA, HMH, SS, SS, HE, SIS, IIS conducted the field work and data collection. AMM, NAI, AMA, WAF oversaw the implementation. HMH, MAA, HMH, SS, SS provided clinical examination for all adolescents during the clinical conveys during conduction of the field work. RMS, AM, DME and SIS did the statistical analyses. RMS, DME, MME shared in the interpretation of the results. RMS drafted the manuscript. AMM \& LEE reviewed the manuscript. AMM \& MHA submitted the manuscript. All authors reviewed the manuscript and approved the final version.

\section{Acknowledgment}

The authors express their appreciation to the funding agency, all women, and their husbands for their willing in participation and cooperation.

\section{References}

1. Crone EA, Konijn EA. Media use and brain development during adolescence. Nat Commun. 2018 Feb 21; 9(1): 588. doi: 10.1038/s41467-018-03126-x.

2. Sawyer SM, Azzopardi PS, Wickremarathne D, Patton G C. The age of adolescence. The Lancet Child and Adolescent Health. 2018 Mar;2(3):223-228. doi: 10.1016/S2352-4642(18)30022-1.

3. Joint press release by UNFPA, UNICEF, WHO, UN Women, the United Nations Foundation, World Vision, Girls Not Brides, Every Woman Every Child, World YWCA and The Partnership for Maternal, Newborn and Child Health.NEW YORK, 7 March 2013. Available at: https://www.un.org/youthenvoy/2013/09/child-marriages-39000-every-day-more-than-140-million-girls-will-marry-between-2011-and-2020/. Accessed 28 November 2020.

4. Abdel-Tawab N, Oraby D, El-Gibaly O, Darwish M, Aziz M, Elgazzar A, Mahmoud H. "Married Adolescent Girls in Rural Assiut and Souhag: Limited Choices and Unfulfilled Reproductive Health Needs." Final Report. Cairo: Population Council.2017.Available at: https://www.popcouncil.org/uploads/pdfs/2017PGY_MarriedAdolGirlsAssiutSouhag.pdf. Accessed 6 December 2020.

5. CAPMAS, 2017. Egypt Census of Population, Housing and Establishments, Egypt. Available at:https://www.capmas.gov.eg/Pages/ShowPDF.aspx? page_id=/Admin/Pages\%20Files/201710914947book.pdf. Accessed 2 January 2021.

6. UNICEF. Policy for action: Issue 1. A product of NCCM Child Rights Observatory. Ending Child Marriage. 1-4. 2019. Available at: https://www.unicef.org/egypt/sites/unicef.org.egypt/files/2018-06/Child\%20Marriage\%20Policy\%20Brief\%20EN\%20FINAL.PDF. Accessed 5 January 2021.

7. Spindler, E., Perlman, D., Chaibou, S., Silverman, J., Carter, N., Boyce, S., Levtov, R., Vlahovicova, K., \&Lauro, G. (2019). Child marriage, fertility, and family planning in Niger: Results from a study inspired by the International Men and Gender Equality Survey (IMAGES). Washington, DC: Promundo-US.

8. Yount KM, Crandall A, Cheong YF. Women's Age at First Marriage and Long-Term Economic Empowerment in Egypt. World Dev. 2018 Feb;102: $124-134$. doi: 10.1016/j.worlddev.2017.09.013. Epub 2017 Nov 5. PMID: 29422706; PMCID: PMC5798478.

9. Metwally AM, El-Sonbaty MM, El Etreby LA, Salah El-Din EM, Abdel Hamid N, Hussien HA, Hassanin AM, Monir ZM. Impact of National Egyptian school feeding program on growth, development, and school achievement of school children. World J Pediatr. 2020 Aug;16(4):393-400. doi: 10.1007/s12519020-00342-8. Epub 2020 Feb 13. PMID: 32056148.

10. Salah El-Din EM, Elabd MA, Nassar MS, Metwally AM, Abdellatif GA, Rabah TM, Shalaan A, Shaaban SY, Kandeel W, El Etreby LA, Al-Tohamy M. The Interaction of Social, Physical and Nutritive Factors in Triggering Early Developmental Language Delay in a Sample of Egyptian Children. Open Access Maced J Med Sci.2019;7:2767-74. Available at: https://www.id-press.eu/mjms/article/view/oamjms.

11. El Din EMS, Rabah TM, Metwally AM, Nassar MS, Elabd MA, Shaalan A, Kandeel W, El Etreby LA, Shaaban SY. Potential Risk Factors of Developmental Cognitive Delay in the First Two Years of Life. Open Access Maced J Med Sci. 2019;7:2024-30. Available at: https://doi.org/10.3889/oamjms.2019.566.

12. Kandeel WA, Rabah TM, Zeid DA, El-Din EMS, Metwally AM, Shaalan A, El Etreby LA, Shaaban SY. Determinants of Exclusive Breastfeeding in a Sample of Egyptian Infants. Open Access Maced J Med Sci. 2018 Oct 2;6(10):1818-1823. doi: 10.3889/oamjms.2018.359. PMID: 30455755; PMCID:

Page 13/17 
PMC6236050

13. Egypt Demographic Household Survey (DHS). Ministry of Health and Population Cairo, Egypt El-Zanaty and Associates Cairo, Egypt. The DHS Program ICF International Rockville, Maryland, U.S.A. 2014. Available at: https://dhsprogram.com/pubs/pdf/fr302/fr302.pdf. Accessed 25 December 2020.

14. Pathfinder International. Launching a New National Strategy for Preventing Child Marriage in Egypt. 2015. Available at https://www.pathfinder.org/articles/launching-new-national-strategy-preventing-child-marriage-egypt/. Accessed 5 December 2020.

15. Egypt Country Brief- Child Marriage in the Middle East and North Africa, United Nations Children's Fund (UNICEF) Middle East and North Africa Regional Office in collaboration with the International Center for Research on Women (IRCW), 2017. Available at : https://www.unicef.org/mena/media/1796/file/MENA-CMReport-EgyptBrief.pdf.pdf. Accessed 29 December 2020.

16. UNFPA, Egypt. United Nation Population Fund: Because everyone counts. 2012: Available at: http://egypt.unfpa.org/english/Staticpage/2/8c040c3a9607-448a-a8c7 b62540496038/Reproductive_Health.aspx (Global Health Council. Field note: Addressing the regional maternal mortality in Egypt. http://www.globalhealth.org/reports/report.php3?id=196). Accessed 12 January 2021.

17. Metwally, A.M., Abdel-Latif, G.A., Mohsen, A, ElEtreby L., . Elmosalami D. M, Saleh R. M., . El-Sonbaty M. M., Amer, H.A.,. El Deeb S. E., Fathy A. M., Hanna C., Azmy O., Taha T. F., Abbassy A., Alalfy M., Hasan H. M. \& Abdelrahman M. Strengths of community and health facilities based interventions in improving women and adolescents' care seeking behaviors as approaches for reducing maternal mortality and improving birth outcome among low income communities of Egypt. BMC Health Serv Res 20, 592 (2020).

18. Metwally AM, Saleh RM, El-Etreby LA, Salama SI, Aboulghate A, Amer HA, Fathy AM, Yousry R, El-Deeb SE, Abdel-Latif GA, Elmosalami DM, Ibrahim NA, Azmy OA, Taha T, Imam HM, Abdel Rahman M, Hemeda SA. Enhancing the value of women's reproductive rights through community based interventions in Upper Egypt governorates: a randomized interventional study. International Journal for Equity in Health.18 Sept 2019;18(1): 146

19. Zamawe C, Banda M, Dube A. The impact of a community driven mass media campaign on the utilization of maternal health care services in rural Malawi. BMC Pregnancy and Childbirth. 2016; 16: 21.

20. Trends in maternal mortality: 1990 to 2013. Estimates by WHO, UNICEF, UNFPA, The World Bank and the United Nations Population Division. World health Organization. 2014. Available at:

https://apps.who.int/iris/bitstream/handle/10665/112682/9789241507226_eng.pdf;jsessionid=600D59FBF919EF4911F470E715C3A79B? sequence=2 Accessed 3Feb 2020.

21. Ministry of Economic Development. Millennium Development Goals Report: 2008- Egypt, Achieving the MDGs. 2010; Midpoint Assessment. Available at:http://ebookbrowsee.net/egypt-mdg-mid-term-assessment-report-2008-pdf-d543877248. Accessed 25 October 2020.

22. UNICEF. Writing a communication strategy for development programs. A Guideline for Program Managers and Communication Officers, Bangladesh. 2008. Available at: http://etoolkits.dghs.gov.bd/sites/default/files/UNICEF\%20Writing\%20a\%20Communication\%20Strategy\%20for\%20Development\%20Programs.pdf. Accessed 5 December 2020.

23. UNICEF. Towards better programming. A handbook on behavior development communication in Water and Environmental Sanitation Programs. Unpublished document, UNICEF WES Technical Guidelines Series No. 4, Program Division Guideline Series, New York. 1999a.

24. UNICEF. Meeting report. Inter-Agency Task Force Consultation on Behavior and Communication from a Rights Perspective. Unpublished document, New York. 1999b.

25. World Bank. Strategic communication for development projects. The international Bank for reconstruction and development. This toolkit was first published in 1996 by the World Bank's Human Development Network under the title communication for behavior change for task managers; 2003.Available at: https://openknowledge.worldbank.org/bitstream/handle/10986/20227/902840WP0Box380C00toolkitwebjan2004.pdf? sequence=1\&isAllowed=y. Accessed 19 December 2020.

26. Fleiss, J. L., Levin, B., Paik, M.C. 2003. Statistical Methods for Rates and Proportions. Third Edition. John Wiley \& Sons. New York. Available at: https://onlinelibrary.wiley.com/doi/pdf/10.1002/0471445428. Accessed 1 November 2020.

27. Newcombe, R. G. 1998. 'Two-Sided Confidence Intervals for the Single Proportion: Comparison of Seven Methods. Statistics in Medicine, 17, pp. 857872.

28. Sheskin DJ. Handbook of parametric and nonparametric statistical procedures. 3rd ed. Boca Raton: Chapman \& Hall /CRC. 2004. Available at: http://fmipa.umri.ac.id/wp-content/uploads/2016/03/David_J._Sheskin_David_Sheskin_Handbook_of_ParaBookFi.org_.pdf. Accessed 22 October 2020.

29. Ammal M. Metwally ,Ghada A. Abdel Latif ,Lobna El Etreby ,Amani Tawfik ,Doaa Elsayed ,Aida M. Abdel Mohsen , Influence of sociodemographic factors and environmental conditions on husbands' behavior toward maternal healthcare, Journal of The Arab Society for the Medical Research, Professional Med. J. -Q. 2015; 10 (1): 18-26, ISSN 1687-4293/2090-3286, DOI: 10.4103/1687-4293.159370

30. Ilene S. Speizer, Lisa Whittle, Marion Carter. Gender Relations and Reproductive Decision Making In Honduras International Family Planning Perspectives. 2005; 31(3):131-139.

31. Kyilleh JM, Tabong PT, Konlaan BB. Adolescents' reproductive health knowledge, choices and factors affecting reproductive health choices: a qualitative study in the West Gonja District in Northern region, Ghana. BMC International Health and Human Rights. $2018 ; 18$ (6).

32. Karki YB. Effects of Communication Campaigns on the Health Behavior of Women of Reproductive Age in Nepal. Further Analysis of the 2006 Nepal Demographic and Health Survey, 2008. Available at : https://dhsprogram.com/pubs/pdf/FA51/FA51.pdf. Accessed 10 December 2020

33. Elwyn G, Frosch D, Thomson R, Joseph-Williams N, Lloyd A, Kinnersley P, et al. Shared decision making: a model for clinical practice. J Gen Intern Med. 2012;27(10):1361-7. 
34. Kruse C, Betancourt J, Ortiz S, Luna S, Bamrah I, Segovia N. Barriers to the Use of Mobile Health in Improving Health Outcomes in Developing Countries: Systematic Review. J Med Internet Res. 2019 Oct 9;21(10):e13263. doi: 10.2196/13263.

35. Nwagwu, W.E. The Internet as a source of reproductive health information among adolescent girls in an urban city in Nigeria. BMC Public Health. 2007. 7, 354. Available from https://doi.org/10.1186/1471-2458-7-354

36. Giorgio MM, Kantor LM, Levine DS, Arons W. Using Chat and Text Technologies to Answer Sexual and Reproductive Health Questions: Planned Parenthood Pilot Study. J Med Internet Res. 2013 Sep; 15(9): e203. doi: 10.2196/jmir.2619

37. Bacchus LJ, Reiss K, Church K, Colombini M, Pearson E, Naved R, Smith C, Andersen K, Free C. Using Digital Technology for Sexual and Reproductive Health: Are Programs Adequately Considering Risk? Global Health: Science and Practice. December 2019, 7(4):507-514; https://doi.org/10.9745/GHSPD-19-00239

38. Dart J, GalloisC, Yellowlees P. Community health information sources, a survey in three disparate communities. Aust Health Rev. 2008; 32 (1): 186-196.

39. Dutta-Bergman MJ. Primary Sources of Health Information: Comparisons in the Domain of Health Attitudes, Health Cognitions, and Health Behaviors. Health Communication. 2004; 16(3).

40. Wakefield MA, Loken B, Hornik RC. Use of mass media campaigns to change health behavior. Lancet. 2010 Oct 9; 376(9748): 12611271. doi: 10.1016/S0140-6736(10)60809-4

41. Goiana-da-Silva F, Cruz-e-Silva D, Carriço M, Teixeira N, Darzi A, Araújo F. Changing the channel: television health campaigns in Portugal. The Lancet public health. 2019; 4(4): Pe179. DOI:https://doi.org/10.1016/S2468-2667(19)30039-8

42. National Research Council (US) and Institute of Medicine (US) Board on Children, Youth, and Families; Fischhoff B, Crowell NA, Kipke M, editors. Adolescent Decision Making: Implications for Prevention Programs: Summary of a Workshop. Washington (DC): National Academies Press (US); 1999. Media Influences. Available from: https://www.ncbi.nlm.nih.gov/books/NBK224108/. Accessed 2 November 2020.

43. Laveaga GS. "'Let's become fewer': Soap operas, contraception, and nationalizing the Mexican family in an overpopulated world." Sexuality Research and Social Policy. September 2007; 4(3): 19-33.

44. Elkamel, F. M. Soap operas may be good for health: impact evaluation of the Egyptian soap opera, 'Family House. Eastern Meditteranean Health Journal. (1998); 4(1): 178-180.

45. Cassidy J. The soap opera that saves lives. BMJ. 2008 May 17; 336(7653): 1102-1103. doi: 10.1136/bmj.39570.422778.3A

46. Metwally AM., Abdel-Latif GA, Saleh RM, Elmosalami DM, Ibrahim NA and Imam HM (2014), Empowerment of Medical and Paramedical Health Providers Role for Achieving the Millennium Development Goal of Reducing Maternal Mortality in Egypt. European Journal of Scientific Research (EJSR), ISSN 1450-216X / 1450-202X, Volume 117 No 1, 2014, p: 7-22

47. Metwally AM, Abdel-Latif GA, Salama SI, Tawfik A, Elmosalami DM, Mohsen AMA. Care seeking behaviors of rural women in Egypt: community-based study. J Appl Sci Res. 2013;9(6):3767-3780. [Google Scholar]

48. Metwally AM, Saad A, Ibrahim NA, Emam HM, El-Etreby LA. Monitoring progress of the role of integration of environmental health education with water and sanitation services in changing community behaviours. Int J Environ Health Res. 2007 Feb;17(1):61-74. doi: 10.1080/09603120600937856. PMID: 17365081.

49. Metwally AM, Ibrahim NA, Saad A, Abu el-Ela MH. Improving the roles of rural women in health and environmental issues. Int J Environ Health Res. 2006 Apr;16(2):133-44. doi: 10.1080/09603120500539208. PMID: 16546806.

50. Metwally AM, Hanna C, Galal YS, Saleh RM, Ibrahim NA, Labib NA. Impact of Nutritional Health Education on Knowledge and Practices of Mothers of Anemic Children in El Othmanyia Village - Egypt. Open Access Maced J Med Sci [Internet]. 2020 Aug. 30 [cited 2021 May 17];8(E):458-65. Available from: https://oamjms.eu/index.php/mjms/article/view/4570

51. Metwally AM, Soliman M, Abdelmohsen AM, Kandeel WA, Saber M, Elmosalami DM, Asem N, Fathy AM. Effect of Counteracting Lifestyle Barriers through Health Education in Egyptian Type 2 Diabetic Patients. Open Access Maced J Med Sci [Internet]. 2019 Aug.20; 7(17):2886-94. Available from: https://www.id-press.eu/mjms/article/view/oamjms.2019.624

52. Metwally AM, Elmosalami DM, Elhariri H, El Etreby LA, Aboulghate A, El-Sonbaty MM, et al. (2021) Accelerating Hepatitis C virus elimination in Egypt by 2030: A national survey of communication for behavioral development as a modelling study. PLoS One. 2021 Feb 23;16(2):e0242257. doi: 10.1371/journal.pone.0242257

53. Shiha G, Metwally AM, Soliman R, Elbasiony M, Mikhail NNH, Easterbrook P. An educate, test, and treat programme to reduce hepatitis C in Egypt: results from a community-based demonstration project. Lancet Gastroenterol Hepatol. 2018 Nov;3(11):778-789. doi: 10.1016/S2468-1253(18)301390 .

54. Metwally A, Mohsen A, Saleh R, et al. Prioritizing High-Risk Practices and Exploring New Emerging Ones Associated With Hepatitis C Virus Infection in Egypt. Iranian Journal of Public Health. 2014 Oct;43(10):1385-1394.

55. Ebtissam M. Salah, Abla G. Khalifa, Ammal M. Metwally, Nabih Abdel Hamid, Hanan A. Hussien and Zeinab M. Moneer: "The Impact Of School Snacks On Cognitive Function Of Primary School Children In Egypt” Journal of Applied Sciences Research, 8(12): 5639-5650, 2012.

56. Metwally AM, El-Sonbaty MM, El Etreby LA, Salah El-Din EM, Abdel Hamid N, Hussien HA, Hassanin AM, Monir ZM. Impact of National Egyptian school feeding program on growth, development, and school achievement of school children (2020): World J Pediatr. 2020 Aug;16(4):393-400. doi: 10.1007/s12519-020-00342-8.

57. Metwally AM, El-Sonbaty M, El Etreby LA, El-Din EMS, Hamid NA, Hussien HA, Hassanin A, Monir ZM. Stunting and its Determinants among Governmental Primary School Children in Egypt: A School-based Cross-sectional Study. Open Access Maced J Med Sci [Internet]. 2020 Sep.15 
;8(B):650-7. Available from: https://www.id-press.eu/mjms/article/view/4757

58. Metwally AM, Shaaban FA, Mahmoud WS, Salah EM, El-Sonbaty MM, Hussien HA, Hamid NA, El Etreby LA, Hassanin A, Monir Z. Vulnerability and Weaknesses of Eating Habits of Overweight School Children as an Entry Risk for COVID-19. Open Access Maced J Med Sci [Internet]. $2020 A u g .30$ [cited 20200ct.18];8(T1):158-66. Available from: https://www.id-press.eu/mjms/article/view/5049

59. Salama II, Sami SM, Said ZN, Salama SI, Rabah TM, Abdel-Latif GA, Elmosalami DM, Saleh RM, Abdel Mohsin AM, Metwally AM, Hassanin Al, Emam HM, Hemida SA, Elserougy SM, Shaaban FA, Fouad WA, Mohsen A, El-Sayed MH. Early and long term anamnestic response to HBV booster dose among fully vaccinated Egyptian children during infancy. Vaccine. 2018 Apr 5;36(15):2005-2011. doi: 10.1016/j.vaccine.2018.02.103. Epub 2018 Mar 9. PMID: 29530634.

60. Salama II, Sami SM, Nabil Z, Said A, El-Sayed MH, El Etreby LA, Rabah TM, Elmosalami DM, Abdel Hamid AT, Salama SI, Abdel Mohsen AM, Emam HM, Elserougy SM, Hassanain Al, AbdAlhalim NF, Shaaban FA, Hemeda SA, Ibrahim NA, Metwally AM. Effectiveness of hepatitis B virus vaccination program in Egypt: Multicenter national project. World J Hepatol. 2015 Oct 8;7(22):2418-26. doi: 10.4254/wjh.v7.i22.2418.

61. A.M.A. Ahmed, M.F. Allam, A.M. Metwally, N.A. Ibrahiem, M. Radwan, M.M.El Gaafary and M.A. Gadallah: "Compliance with haemodialysis practice guidelines in Egypt". East Mediterr Health J. 2013 Jan;19(1):4-9.

62. A.M. A. Ahmed, Mohd. F. Allam, E. S. Habil, A. M. Metwally, N. A. Ibrahiem, M. Radwan, M. M. El-Gaafary, A. Afifi and M. A. Gadallah: “Development of practice guidelines for hemodialysis in Egypt”. Indian J Nephrol. 2010 Oct;20(4):193-202. doi: 10.4103/0971-4065.73450.

63. CIOMS/WHO. International Ethical Guidelines for Biomedical Research Involving Human Subjects. Geneva: CIOMS. 1993.

\section{Figures}

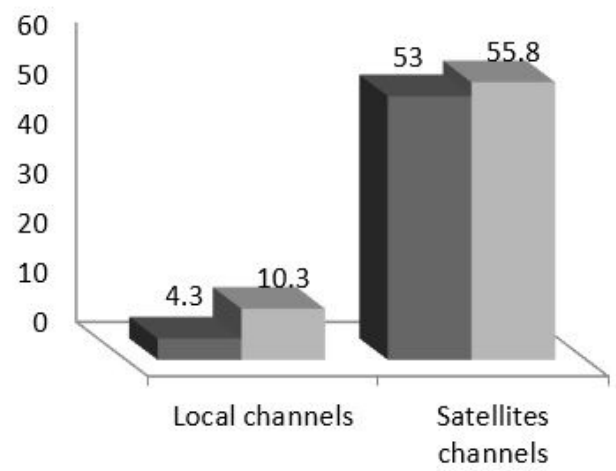

Wives Husband

Figure 1

Favorite TV Channels (Managerial Feasibility) \# \#Percentage calculated out of those who reported that they are watching

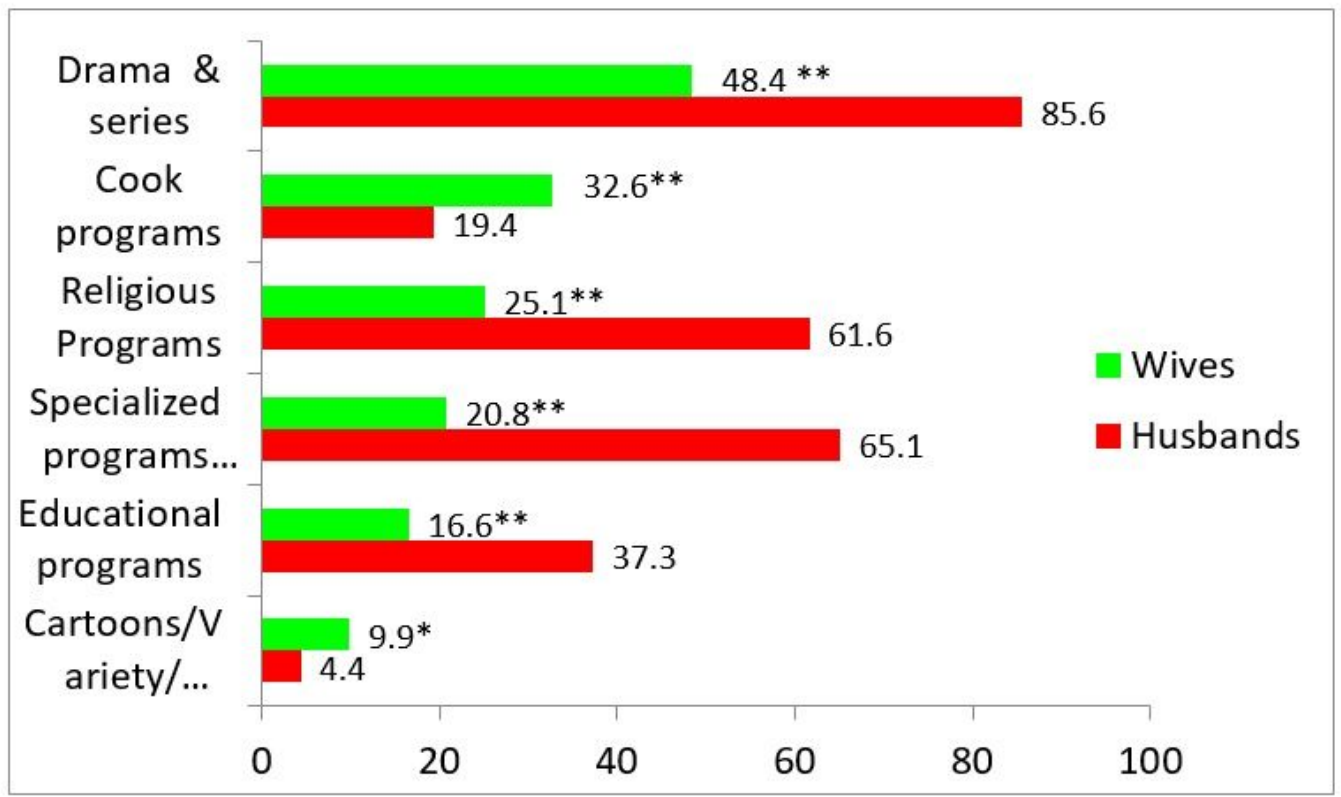


Figure 2

List of Favorite Programs in TV, Upper Egypt N.B. ** = highly significant statistical difference, * = significant statistical difference 